\title{
Liver Preservation: The Past and the Future
}

\author{
JAN D. BlankENSTEIJN* AND ONNO T. TERPSTRA \\ Department of Surgery, University Hospital "Dijkzigt," Erasmus University, 3015 GD Rotterdam, The Netherlands
}

The ultimate objective of organ preservation is unrestricted and immediate graft function after a transplant under optimal conditions in the most suitable recipient. This means that time and efficacy are the basic features of the search for the ideal preservation method. Theoretically, freezing and continuous aerobic perfusion are the only means of obtaining truly long-term preservation (from a month to years). From a clinical point of view, however, the preferred method of preserving livers for brief periods before transplantation is simple cold storage (1).

Until recently, cold storage of the graft in Collins' solution provided acceptable graft function when preservation time was $8 \mathrm{hr}$ or less (2). Still, in the first report of the European Liver Transplant Registry (3), reviewing 1,315 liver transplantations performed at 32 different centers from 1968 to 1987, one of the principal causes of loss of the graft (and occasionally of death of the patient) appeared to be the so-called "primary nonfunction" of the liver. In most cases this was thought to be through an injury caused by inadequate preservation. To keep the period of cold storage to a minimum, close coordination of two full surgical teams - one for the donor and one for the recipient - was necessary, and the recipient operation had to be performed as an emergency procedure, often at night. Furthermore, only a very narrow margin of safety existed in the storage time, in case of unforeseen delays or unanticipated, timeconsuming difficulty in the recipient operation.

To evaluate the possibility of liver transplantation on a (semi-) elective basis, Belzer (4) looked at the clinical needs for preservation times and concluded that 12 to 18 $\mathrm{hr}$ was necessary for liver transplantation to be performed electively.

Similar to kidney transplantation, (semi-) elective liver transplantation will yield substantial benefits: because simultaneous donor and recipient operations are not required, an unnecessary recipient laparotomy may be prevented if the donor organ appears unsuitable for transplantation. Furthermore, if laparotomy findings indicate that the recipient is unsuitable for

Received November 2, 1989; accepted July 31, 1990.

*Current address: Department of Surgery, Zuiderziekenhuis, Groene Hilledijk 315, 3075 EA Rotterdam, The Netherlands.

Address reprint requests to: J. D. Blankensteijn, Department of Surgery, Zuiderziekenhuis, Groene Hilledijk 315, 3075 EA Rotterdam, The Netherlands. $31 / 1 / 29378$ transplantation, extended preservation gives time for another patient to be prepared for transplantation. Because organs can be procured before final arrangements are made for the recipient, timing of the donor operation will be less critical; this will have particular merit when the donor's condition is unstable. This implies an increase in efficiency of organ utilization and the number of donor organs. Extended preservation will also allow for more preparation time and well-rested support in anesthesia, nursing, operating room, blood bank and intensive care unit. The fact that the same surgeon can perform the donor operation and-after a rest period - the recipient operation, will allow recipient hepatectomy to be tailored for the donor organ.

With the development of the University of Wisconsin (UW) solution (5) it is claimed that the goal of semielective liver transplantation has been achieved $(6$, 7). Without a doubt, however, the search for improving available preservation methods will continue. Preservation times of more than 12 to $18 \mathrm{hr}$ will be necessary to enable assessment of the viability of the harvested organ, to apply immunomodulation of the recipient and to perform cross-matching based on analysis of tissue antigens. Although the importance of cross-matching in liver transplantation remains to be determined, repeat transplant candidates and highly sensitized patients may benefit from tissue typing.

The main objective of this study was to summarize the history of organ preservation and to integrate the reported potential mechanisms of preservation damage to a generally applicable hypothesis on liver harvesting injury. This hypothesis was then used to discuss the rationale of the basic components of the UW solution and its current and future additives.

\section{HISTORY OF ORGAN PRESERVATION}

The first experiments in transplantation of the whole liver were hampered by the extreme sensitivity of this organ to anoxia $(8,9)$. In 1956, Goodrich et al. (9) showed that normothermic complete anoxia for a period of 30 min rendered the liver unsuitable for transplantation.

The earliest device developed to protect the harvested liver was based on hypothermia: Starzl et al. (10) induced hypothermia by whole-body cooling of the donor to $30^{\circ} \mathrm{C}$ and then perfused the excised liver with cold Ringer's lactate solution. In this way the hepatic core temperature fell to approximately $15^{\circ} \mathrm{C}$. These organs then appeared to be able to sustain life in recipient dogs 
if transplanted as orthotopic homografts within two hours. Although Sicular and Moore (11) demonstrated that canine liver cells in vitro stored at hypothermia remain functionally intact for about $4 \mathrm{hr}$ after death, longer anoxic times in Starzl's experiments resulted in a high rate of acute failure due to outflow block of the transplants, hemorrhagic diathesis and acute liver failure. Whereas the problem of outflow block was likely to be caused by spasm of the intrahepatic veins of the dog, hemorrhagic diathesis and acute liver failure, as would become evident later, were mainly the result of poor liver preservation.

In the history of organ preservation, experiences in kidney and liver preservation frequently supplemented one another. Since the previously mentioned technique of infusion of cold electrolyte solution was the first effective method in liver preservation, it immediately became the standard for the quick cooling of the kidney (12). In 1963, Calne and coworkers (13) concluded their report on renal preservation by ice cooling as follows: "The cooling and rewarming periods can be reduced by perfusion techniques, which may be especially pertinent to the clinical application of cadaver transplants, since there is an inevitable delay in removing the kidney after death, and the relative large mass of the human kidney takes longer to cool by surface methods." Obviously, this remark was even more appropriate for the large mass of the human liver. Consequently, most initial efforts to extend storage time were based on the concept of continuous hypothermic perfusion of the graft. In 1963, Marchioro and associates (14) reported a method of hypothermic cadaver perfusion with the use of an extracorporeal heart-lung machine. In 1965, Mikaeloff et al. (15) described an application of a method, reported in 1961 by Kestens and McDermott (16), in which hypothermic perfusion in situ was confined to the liver. Long-term recipient survival after homotransplantation of canine livers removed as long as $6 \mathrm{hr}$ after death was achieved applying this technique.

Other methods not based on continuous perfusion were also assessed. Brown et al. (17) and Moss, Reed and Riddell (18) evaluated preservation by means of freezing to $-6^{\circ} \mathrm{C}$ and $-20^{\circ}$ to $-60^{\circ} \mathrm{C}$, respectively. Organs preserved for 1 to 14 days in these experiments, however, were incapable of supporting life as orthotopic transplants.

In 1967, a few years after Calne et al. (13) had stressed the importance of hypothermia in kidney preservation, Belzer, Ashby and Dunphy (19) demonstrated that 24-hr and 72-hr preservation of canine kidney was feasible by means of extracorporeal hypothermic pulsatile perfusion. In the same year, Slapak, Wigmore and McLean (20) reported 24-hr preservation of the canine liver with a hypothermic, hyperbaric pulsatile perfusion technique. The latter results, however, were achieved by transplanting the liver in the neck of the recipient animal; therefore it could not be established whether this method would be adequate to maintain the life of a hepatectomized animal. In fact, it soon became clear that compared with kidney transplantation, progress in preservation techniques of the liver was far less prevalent.

On March 1, 1963, the first human liver transplantation was performed by Starzl in Denver (21). Reviewing 15 cases of clinical liver transplantation performed between 1963 and 1965 (22), Schalm et al. (23) noted that all homografts, except in one case, were revascularized within 3 to $3 \frac{1}{2} \mathrm{hr}$ of the death of the donor. Therefore they designed a preservation method of simple cooling and flushing of the liver in situ with a nonphysiological perfusion fluid, which was then replaced by infusion of a plasma-based preservation fluid. The latter was intended to keep the vascular bed of the liver as intact as possible. This method provided a reliable preservation of about $3^{1 / 2} \mathrm{hr}$ of the liver homograft, as confirmed by successful heterotopic nonauxiliary transplantation in the dog. This technique was then adapted and successfully used in the Cambridge-King's College Hospital liver transplant program (24). Simultaneously, Collins, BravoShugarman and Terasaki (2) reported successful canine kidney preservation with a similar technique of initial perfusion and 30-hr ice storage. Again, as with continuous perfusion techniques, progress in kidney preservation was far ahead of liver preservation. The Denver/Pittsburgh group subsequently started using the "Collins C2" formulation in liver transplantation (25). From that time on, two different pathways of liver preservation were continuously explored: the complex method of continuous or intermittent perfusion and the method of initial perfusion followed by simple hypothermic storage.

Continuous Perfusion. In 1968, Brettschneider et al. (26) demonstrated that homografts could be effectively preserved for $8 \mathrm{hr}$ with a combination of hypothermia, hyperbaric oxygen and continuous perfusion with diluted homologous blood through the portal vein and the hepatic artery. Another, relatively simple technique using continuous, hypothermic, asanguinous perfusion with cryoprecipitated plasma, which appeared to be consistently effective up to $10 \mathrm{hr}(27)$, was not capable of successfully preserving porcine livers for $24 \mathrm{hr}$ (28).

Although the Cambridge group continued to use the previously described modified plasma protein solution clinically, the limitation of 3 to $4 \mathrm{hr}$ for hypothermic storage in many cases resulted in transplantation operations outside their own institution, with transfer of medical and nursing personnel and the recipient to the hospital where the donor had died. This caused many logistic problems and encouraged the Cambridge group to search for an improvement of the complicated continuous perfusion apparatus with hyperbaric oxygen, which was available at that time. They developed a single-passage, hypothermic, intermittent "squirt" perfusion technique that allowed preservation of porcine liver for up to $17 \mathrm{hr}(29)$.

In the following $15 \mathrm{yr}$, relatively little progress was made, and although a few reports showed successful 24-hr preservation $(30,31)$ and even incidental graft survival after $48 \mathrm{hr}$ (32) preservation by perfusion 
techniques, the diverse results merely reflected the problems in establishing a consistent technique. Among other factors, the type and length of preservation, the chemical characteristics of the perfusate, the actual technique of perfusion (intermittent/continuous, pulsatile/nonpulsatile) and the individual response of the liver to hypothermic preservation were responsible for variations in the results. Moreover, continuous perfusion techniques have the disadvantages of being expensive, technically complex, bulky and not easily portable. Therefore these methods found little favor in clinical practice.

Just before the breakthrough in liver preservation discussed below, continuous hypothermic perfusion with a modified isotonic citrate solution was described as providing reliable 48 -hr preservation of rat liver (33). In addition, promising results were recently reported by Nakajima et al. (34), who used an artificial blood substitute based on a stabilized hemoglobin solution. Successful 48-hr preservation of the canine liver was achieved by continuous hypothermic perfusion, with viability assessed by orthotopic transplantation.

Simple Hypothermic Storage. In 1971, Abouna et al. (35) and Spilg et al. (36) reported successful liver transplantation after simple cold storage of the graft for 6 to $8 \mathrm{hr}$, using balanced salt solutions to which dextrose was added. After the initial perfusion in the experiments of Spilg et al., livers were stored in a second solution that was mainly composed of fresh frozen plasma. The solution Abouna used for graft storage was almost the same as the flush solution. Except in the report of Mieny and Myburgh (37), who successfully transplanted four baboon livers after 20 -hr preservation with a chilled dextran-electrolyte-sorbitol solution, until 1979 reliable preservation time remained well under $12 \mathrm{hr}$ : in 1977, Benichou et al. (25) reported a comparison between Ringer's lactate, Schalm's solution as modified by Wall et al. (24) and Collins' solution (2). Surprisingly, all three fluids appeared effective in preserving liver grafts for $9 \mathrm{hr}$; this was much longer than one would be led to expect by the previous reports on simple cold storage, particularly with regard to Ringer's lactate. Benichou et al. concluded therefore that hypothermia is the most important determinant for success in short-term preservation, no matter the solution. However, the extra value of the special composition of a solution became clear in 18-hrs cold storage: Ringer's lactate yielded significantly worse results than did the other two solutions. In the same report these authors described clinical preservation with a modified Collins' solution in seven patients, with preservation times varying from $6 \frac{1}{2}$ to $10 \mathrm{hr}$. Subsequently, most centers started to use the modified Collins' solution or its more recent derivative, Euro-Collins, for human liver preservation (38) and continued to do so until 1988. In that year UW solution dramatically improved liver preservation by simple cold storage; this will be described below.

The only report of successful preservation by simple cold storage, preceding the UW solution era, was in a model with auxiliary liver transplantation (39). Toledo-
Pereyra and associates (39) showed that it is possible to store canine livers hypothermically for $24 \mathrm{hr}$ after flushing with crystalloid or colloid hyperosmolar solutions. They used Sacks' solution, which is comparable to Collins' solution (40), as crystalloid hyperosmolar solution, and as colloid hyperosmolar solution they used the modified silica gel fraction of plasma (developed by the same group [30]), which is comparable to the Cambridge modification of Schalm's solution (24). These favorable results with auxiliary transplantation are even more conspicuous when the results of a similar experiment conducted by Tamaki, Kamada and Pegg in 1985 (41) are taken into account: they were able to preserve liver grafts for a cold ischemic period of only $6 \mathrm{hr}$, but completely failed to do so for $18 \mathrm{hr}$, using Collins' solution and the modified Schalm's plasma protein fraction solution in orthotopic transplantation in the rat.

Recently, Belzer and Southard at the University of Wisconsin (Madison, WI), succeeded in producing a remarkably effective solution for liver preservation, the so-called UW-solution (5). It was conceived on the basis of a thorough understanding of organ damage and protection mechanisms. This knowledge was gathered by extensive analysis of the basic principles of anaerobic hypothermic ischemia and organ-specific metabolism. Therefore, before the development of UW solution is explained, various basic aspects of harvesting injury to the liver are elucidated in the next section.

\section{MECHANISMS OF HARVEST INJURY}

Literature provides numerous reports that merely focus on one or two of the determinants of the multifactorial pathogenesis of harvesting injury. This may lead to seemingly inconsistent results. Apart from the fact that various experimental designs are used in different animal models, the most prominent determinants of these contradictions are anoxic vs. reperfusion damage, parenchymal vs. nonparenchymal damage and warm and cold ischemia.

After removal of an organ from the circulation of the donor, the most logical way of keeping the harvested organ viable is perfusion by oxygenated whole blood with a heart-lung machine. The results and dilemmas of this approach are already described above. Any practical preservation method should consist of the (temporary) withdrawal of blood flow from the organ, which necessitates a period of ischemia after organ procurement and a moment of reperfusion during the recipient procedure. Injury may be induced by ischemia (literally, absence of blood) per se because it necessitates flushing of the donor organ, which in its turn may result in interstitial and cellular swelling when inappropriate fluids are used. This is, however, usually not the type of organ damage denoted by the expression "ischemic damage." In fact, it is a misnomer because hypoxia or anoxia is what is generally referred to, and "anoxic damage" would be a better term (42). Anoxic and reperfusion damage are the two principal mechanisms of harvest injury. Accordingly, for these mechanisms, differences between paren- 
chymal and nonparenchymal damage and between warm and cold ischemia are discussed separately.

Anoxic Damage. In aerobic cells the energy necessary to maintain cell integrity is supplied by the mitochondrial cytochrome system through complete (tetravalent) reduction of oxygen to water. This involves the generation of ATP, by which means the energy is stored for later consumption (oxidative phosphorylation). These terminal reactions in aerobic glycolysis need a continuous supply of oxygen. As cells become anoxic, oxidative phosphorylation ceases and - without precautions - the stored ATP is consumed very rapidly. Since practically all energy-dependent functions use ATP, this molecule plays a central role in the viability of cells. Lack of ATP leads to cell injury by impairment of energy-dependent intracellular homeostatic functions. Subsequent to ATP depletion, diverse sequelae culminate in lethal cell injury. Therefore ATP can be considered the initial common pathway of cell death in organ preservation.

The pathway from ATP deficit to irreversible cell damage is obscure. However, some microscopic aspects of the cell surface (i.e., loss of microvilli and "blebbing") seem to be fairly constant. Cell surface blebbing is described by Lemasters et al. (43) in a sequence of events in which the sudden progression from reversible to irreversible injury is associated with and considered to be caused by rupture of a terminal cell surface bleb. Blebbing is thought to be a direct result of disruption of the cytoskeleton. Since cellular microfilaments and microtubules, of which this cytoskeleton is composed, are in an energy-requiring, dynamic state of continuous formation and disassembly, ATP deficiency may be directly related to this phenomenon. Other mechanisms, however, are suggested also and will be discussed below.

ATP can be saved by cooling the organ, which reduces the tissue's metabolic demands for nutrients and oxygen. Therefore, hypothermia plays an essential role in the preservation of the anoxic cell. Alone, it is effective in prolonging the time during which anoxic tissue will remain viable (6). However, this advantage is gained at a price because the intracellular homeostatic functions are decelerated equally. All measures that must be taken to prevent damage from loss of cellular homeostatic capacity constitute the toll for hypothermia-induced reduction of the metabolic rate. Although theoretically the cell will ultimately be confronted with the same dangers as in warm ischemia, viability will be jeopardized earlier through changes induced by the loss of homeostatic capacity. Obviously, in the process of extending the cold-ischemic period, when the most important obstacle is overcome, progress will go just as far as the second, most important metabolic disturbance allows. In addition, every measure in itself has the potential of introducing new threats for the already compromised cells.

Disturbance of the electrolyte balance is a major consequence of slowing the metabolism by hypothermia. Normally, the cells are bathed in an interstitial fluid high in sodium $\left(\mathrm{Na}^{+}\right)$and calcium $\left(\mathrm{Ca}^{2+}\right)$ and low in potassium $\left(\mathrm{K}^{+}\right)$, compared with the intracellular electrolyte concentrations (44). The intracellular concentrations of $\mathrm{Na}^{+}$and $\mathrm{K}^{+}$are maintained by an energydependent cation transport system in the cell membrane $(45,46)$. This enzyme system, $\mathrm{Na}^{+} / \mathrm{K}^{+}$-activated (ATPase) uses ATP to make $\mathrm{Na}^{+}$impermeable outside the cell, counteracting the colloidal osmotic pressure derived from the intracellular proteins and other impermeable anions, and causes $\mathrm{K}^{+}$to accumulate in the cell. Hypothermic preservation suppresses the activity of this $\mathrm{Na}^{+}$pump and decreases the membrane potential of the plasma membrane. Consequently, chloride $\left(\mathrm{Cl}^{-}\right)$enters the cell down a concentration gradient with a cation and water to cause cell edema (4). Because this process leads to progressive cellular destruction, retention of intracellular electrolytes is a primary requirement for successful organ preservation (47).

The extracellular fluid is very rich in calcium $\left(\mathrm{Ca}^{2+}\right)$ $\left(10^{-3} \mathrm{M}\right)$ compared with the intracellular $\mathrm{Ca}^{2+}$ concentration $\left(10^{-6} \mathrm{M}\right)$. In addition, the electrical potential across the plasma membrane tends to drive $\mathrm{Ca}^{2+}$ in the cells. Such a large electrochemical gradient is maintained by the relative impermeability of the plasma membrane to $\mathrm{Ca}^{2-}(48)$ and by active extrusion from the cell.

Some considerations must be given at this point to the matter of the $\mathrm{Ca}^{2+}$ being a biological messenger. It has been more than a century since Ringer (49) noticed that isolated hearts did not beat in the absence of $\mathrm{Ca}^{2+}$. Although $99 \%$ of $\mathrm{Ca}^{2+}$ in the human body is present in the bones, it is nowadays clear that $\mathrm{Ca}^{2+}$ plays a unique role in transmitting "signals" generated at the plasma membrane to a large number of target functions inside the cell (50). The intracellular $\mathrm{Ca}^{2+}$ modulated (enzyme) functions are adjusted by variations in $\mathrm{Ca}^{2+}$ activity in a narrow range, around $\mu \mathrm{mol} / \mathrm{L}$. Therefore the messenger function requires that intracellular $\mathrm{Ca}^{2+}$ be maintained at a very low activity level to switch targets on and off. This is achieved in two ways: by complexing the $\mathrm{Ca}^{2+}$ that has entered the cell down the concentration and electrical gradient from the extracellular space and by transporting the $\mathrm{Ca}^{2+}$ reversibly across various membrane systems. Three membrane systems have been shown able to transport $\mathrm{Ca}^{2+}$ : the plasma membrane, the sarcoplasmatic and endoplasmatic reticulum and the mitochondrion. The intracellular $\mathrm{Ca}^{2+}$. transporting membranous network probably predominates over the plasma membrane in the rapid regulation of $\mathrm{Ca}^{2+}(50)$.

The type of interaction between $\mathrm{Ca}^{2+}$ and the target molecule is, in most cases, not known. However, in the last few years a small-molecular-weight protein has been discovered to be an important factor mediating the transmission of the $\mathrm{Ca}^{2+}$ signal and its interaction with the target function (Table 1). This ubiquitous molecule, discovered by Cheung in 1967 (51), is termed "calmodulin." It is inactive in itself, the active form being the $\mathrm{Ca}^{2+}$-calmodulin complex, which binds reversibly to the target enzyme (50).

Besides $\mathrm{Ca}^{2+}$, another important biological mes- 
senger has been identified: cyclic AMP (cAMP) (52). However, complications are added to the issue by the fact that the $\mathrm{Ca}^{2+}$-calmodulin complex activates two key enzymes with opposite functions in the metabolism of cAMP: adenylate cyclase (generation) and phosphodiesterase (breakdown).

Obviously, at the current stage it is impossible to present a reasonable generalized model of the exact role of $\mathrm{Ca}^{2+}$ in cell death. However, because a large number of $\mathrm{Ca}^{2+}$ membrane transport systems appear to have been invoked by evolutionary pressure, the importance of the messenger function of $\mathrm{Ca}^{2+}$ and the resulting necessity of regulating its activity inside cells with utmost efficiency and precision cannot be overlooked.

Several ways exist by which warm and cold ischemia may lead to altered $\mathrm{Ca}^{2+}$ homeostasis (53). Depletion of ATP stores inhibits the ATP-dependent pumps to extrude $\mathrm{Ca}^{2+}$ from the cell and the energy-dependent shuttles of the organelle membranes. In addition, the decrease in $\mathrm{pH}$ will induce a release of normally complexed $\mathrm{Ca}^{2+}$ as free ions. Other ions may also be related to pathological fluxes of $\mathrm{Ca}^{2+}$-for instance, the $\mathrm{Na}^{+} / \mathrm{K}^{+}$homeostasis, which is also seriously changed during ischemia, as described above. Cold ischemia in particular leads to decreased membrane fluidity, which in itself - or in combination with cellular swelling - may be related to abnormal $\mathrm{Ca}^{2+}$ movement. Considerable evidence shows that cytosolic changes in $\mathrm{Ca}^{2+}$ levels are evoked both by release from intracellular depots and by pathologic influx through the plasma membrane (54-56). Unless the extrusion of $\mathrm{Ca}^{2+}$ from the cell is also influenced, only a transient increase in cytosolic $\mathrm{Ca}^{2+}$ level would be expected after the release of $\mathrm{Ca}^{2+}$ from intracellular stores (57).

Many studies have associated these elevated $\mathrm{Ca}^{2+}$ levels with biochemical changes and histological damage and cell death $(53,57,58)$. In an interesting report, Schanne and associates (48) described how accumulating intracellular $\mathrm{Ca}^{2+}$ can induce cell death. They found that rat hepatocytes can be destroyed with the cytotoxic compound A23187, whose only known specific biological activity is to create $\mathrm{Ca}^{2+}$ channels that overcome the permeability barrier of the plasma membrane. Furthermore, these investigators showed an absolute requirement for extracellular $\mathrm{Ca}^{2+}$ in the killing of primary cultures of adult rat hepatocytes by nine other toxins. Because all the toxins they used are capable of interacting with cell membranes, an interpretation of this $\mathrm{Ca}^{2+}$ dependence in cell death is that each agent requires extracellular $\mathrm{Ca}^{2+}$ to produce membrane injury. Besides the fact that it seems very unlikely that all 10 toxins would be dependent on $\mathrm{Ca}^{2+}$, some of these agents have been shown capable of producing membrane disruption without the presence of $\mathrm{Ca}^{2+}$. Therefore the most plausible explanation is that in each case, the toxin causes disruption of the permeability barrier function of the plasma membrane, allowing a lethal influx of $\mathrm{Ca}^{2+}$ down the steep electrochemical gradient between the outside and the inside of the cell.

The exact way in which $\mathrm{Ca}^{2+}$ brings about cell death
Table 1. Calmodulin-regulated enzymes or cellular processes

Phospholipase $\mathrm{A}_{2}$

Phosphodiesterase

Phosphorylase B kinase

Membrane phosphorylation

Ca-pumping ATPase (red cells)

Ca-pumping ATPase (sarcoplasmatic reticulum)

Adenylate cyclase

Guanylate cyclase

Myosin light chain kinase

Neurotransmitter release

Microtubules disassembly

is open to speculation. $\mathrm{Ca}^{2+}$ plays a critical role in the maintenance of the structure and function of platelet cytoskeleton: Bellomo and Orrenius (57) described menadione-induced oxidative stress on the platelet cytoskeleton to be $\mathrm{Ca}^{2+}$-dependent, either as a direct consequence of the increase of cytosolic $\mathrm{Ca}^{2+}$ or mediated through the activation of $\mathrm{Ca}^{2+}$-dependent proteases. Blebbing as described above is therefore frequently associated with elevated $\mathrm{Ca}^{2+}$ levels. However, Lemasters et al. (43) demonstrated blebbing of hepatocytes in a model of chemical hypoxia without a rise in cytosolic $\mathrm{Ca}^{2+}$. This controversy may be due to the variety of mechanisms by which $\mathrm{Ca}^{2+}$ homeostasis is thought to be altered and to dissimilar relative importance of these mechanisms in both cold and warm ischemia. On the other hand, it means that disturbances in the cytoskeleton and cell surface blebbing are not exclusively caused by $\mathrm{Ca}^{2+}$ increase.

Another possible mechanism of $\mathrm{Ca}^{2+}$-induced damage is activation of phospholipases (59). These enzymes remove fatty acids from membranes without the aid of oxygen. Since catabolism of fatty acids does require oxygen, fatty acids accumulate and the bilayer membrane configuration is disturbed (53).

In addition, $\mathrm{Ca}^{2+}$ is a regulator of a number of proteases, of which the conversion of xanthine dehydrogenase (XD) to xanthine oxidase (XO) is thought to play a significant role in the origin of preservation damage (60). However, the deleterious effects of phospholipase and protease activation may be of more importance during reperfusion, which will be discussed below.

Although the rate of metabolism is greatly reduced under cold-storage conditions, the cell still needs some energy. In the absence of oxygen, the cell is able to draw this energy from anaerobic glycolysis and glycogenolysis, which entail increased production of lactic acid and hydrogen ions. The resulting tissue acidosis can damage cells and induce lysosomal instability, activate lysosomal enzymes and alter mitochondrial properties (5). On the other hand, mild extracellular acidosis has been shown to be protective against the onset of irreversible injury to hepatocytes during ischemic stress $(61,62)$. In hepatocytes depleted of ATP by chemical hypoxia, Gores et al. (63) showed this protective effect of cellular acidosis to be mediated by intracellular $\mathrm{pH}$. In that report, because 


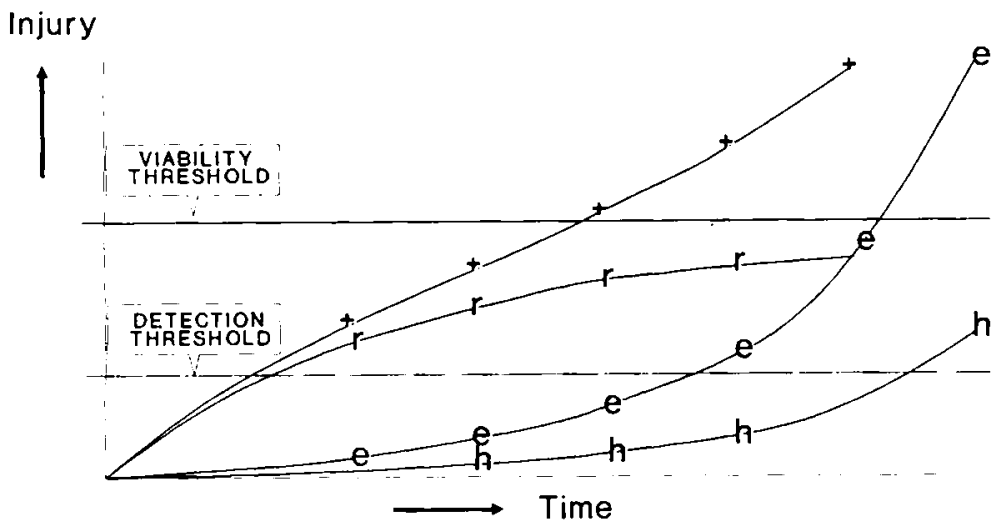

FIG. 1. Harvest injury from cold ischemia as measured by several biochemical and structural studies. The total amount of damage $(+)$ is split into its components: anoxic damage to hepatocytes $(h)$, anoxic damage to endothelial cells $(e)$ and reperfusion damage $(r)$. This graph shows that endothelial damage always exceeds hepatocyte damage. In addition, we show that reperfusion damage will initially be the most important factor (detection threshold). In extended ischemic periods, however, measures to prevent reperfusion damage will no longer be able to inhibit the total amount of injury to progress beyond the viability threshold.

TABLE 2. Cellular free radical targets

\begin{tabular}{ll}
\hline \multicolumn{1}{c}{ Target } & Consequence \\
\hline "Small" molecules & \\
Unsaturated and thiol-containing & $\begin{array}{c}\text { Protein denaturation and cross-linking, enzyme inhibition, organelle and cell permeability } \\
\text { changes } \\
\text { Nucleic acid bases }\end{array}$ \\
Cell cycle changes, mutations \\
Unsaturated lipids & Cell surface receptor changes \\
Cofactors & Cholesterol and fatty acid oxidation, lipid cross-linking, organelle and cell permeability changes \\
& Decreased nicotinamide and flavin-containing cofactor availability and activity, ascorbate oxi- \\
Neurotransmitters & dation, porphyrin oxidation \\
Antioxidants & Decreased neurotransmitter availability and activity, including serotonin and epinephrine \\
Macromolecules & Decreased availability, including $\alpha$-tocopherol and $\beta$-carotene \\
Protein & Peptide chain scission, denaturation \\
DNA & Strand scission, base modification \\
Hyaluronic acid & Change in synovial fluid viscosity \\
\hline
\end{tabular}

anaerobic glycolysis is also inhibited in chemical hypoxia, the most important source of intracellular acidosis was considered hydrolysis of ATP. The mechanism of this protection by intracellular acidosis is unknown, but it is hypothesized that acidic $\mathrm{pH}$ suppresses autolytic degradative processes by proteases and phospholipases activated by ATP depletion as described above.

Most of the above-mentioned experiments focus on the hepatocyte. It is, however, well established that in ischemia endothelial lesions appear earlier than do parenchymal lesions. This concerns both warm (64) and cold (64-66) ischemic damage. Although the parenchymal cells may be viable after a certain period of preservation, graft survival will not be achieved when endothelial cells are lethally injured. This may explain the dissociation between functional tests of preserved hepatocytes and graft survival.

Focusing on cold ischemic damage only, it appears that microcirculatory damage will always be the critical factor. The correlation between the duration and the amount of anoxic damage (i.e., injury without reper- fusion) to parenchymal and nonparenchymal cells and of reperfusion injury, as measured by several biochemical $(67,68)$ and structural $(64-66)$ studies, is depicted in Figure 1.

Although Holloway et al. (65) demonstrated that UW solution and isotonic citrate solution provide significant protection against injury to the hepatic microcirculation by cold preservation, they could not identify the mechanisms by which this protective effect was induced. In addition, evidence has accumulated showing that microcirculation suffers mostly at and after reperfusion.

Anoxic damage through basis of warm ischemia may be partially caused by ATP depletion in itself and by the ensuing disturbances in the cytoskeleton. Because $\mathrm{Ca}^{2+}$ accumulation needs some time and because low temperatures render organelles especially susceptible to cytosolic $\mathrm{Ca}^{2+}$ changes (69), elevated $\mathrm{Ca}^{2+}$ levels may be the most important pathway through which cold ischemic damage is induced, the decisive factor being the sinusoidal lining cells. This damage, however, will probably not be manifest until the moment of reperfusion. 
Cytochrome oxidase complex

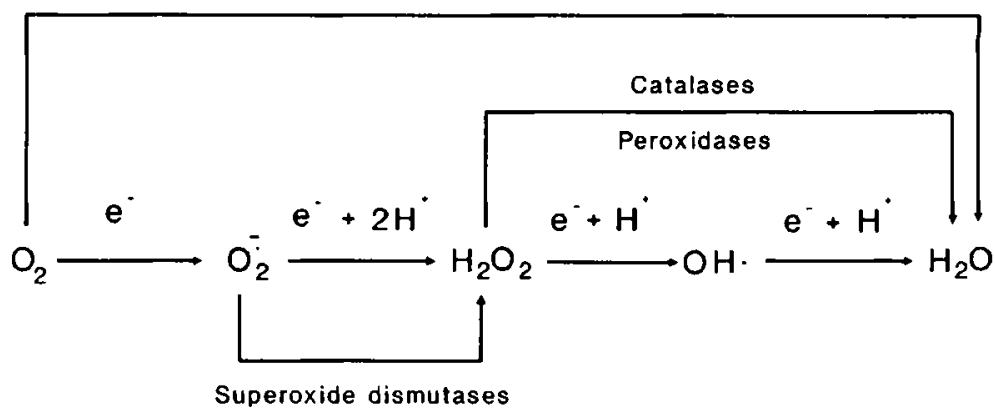

FIG. 2. The univalent pathway for reduction of molecular oxygen. The enzymatic defense mechanisms to bypass and prevent the accumulation of reactive intermediates are also shown.

Reperfusion Damage. It is well established that many organs suffer from considerable damage induced immediately after a period of either warm or cold ischemia at reperfusion (70). The ischemic intestine $(71,72)$ and lung $(73,74)$ have been shown to be particularly susceptible to this reperfusion injury, and involvement of oxygen-derived free radicals in the pathophysiology of the cell damage has been suggested. Postischemic injury as a consequence of generation of cytotoxic metabolites of oxygen may also be significant in other organs, including the kidney (75-77), heart $(78-80)$, pancreas (81), liver (82) and skin (83). Because oxygen-derived free radicals appear to play such an important role in the mechanism of reperfusion injury, the background of oxygen-derived free radicals will be reviewed first.

Oxygen-derived Free Radicals. A normal chemical bond consists of a pair of electrons sharing a single molecular orbit. A free radical is any atom, group of atoms or molecule that has one unpaired electron occupying an outer orbit (84). This should not be confused with ions whose positive $\left(\mathrm{Na}^{+}\right)$or negative charge $\left(\mathrm{Cl}^{-}\right)$depends on the relationship of the number of electrons to the number of protons. Free radicals may be considered to contain an open bond or half a bond, rendering them chemically highly reactive and, therefore, transient. In chemical formulas the odd electron is symbolized by a dot. Free radicals can occur in both organic (e.g., quinones) and inorganic molecules (e.g., $\mathrm{O}_{2}{ }^{-}$) and are critical in the normal operation of a wide spectrum of biological processes (85).

Biological reactions concerning free radicals can be classified as initiation reactions, propagation reactions and termination reactions (84). The formation of a free radical, for instance, by radiolysis, photolysis or during oxidation-reduction reactions, is termed initiation. Free radicals can then proceed further by free radical intermediates, termed propagation reactions, which may be thousands of events long. If two radicals react, both radicals are eliminated from the propagating pool: this is termination. Virtually all cell components are capable of reacting with free radicals. Chemical modification of these molecules leads to metabolic and structural mod- ifications of cells that can ultimately cause cell death. Notable cellular components at risk from free radical damage include proteins, membrane lipids, nucleic acids and DNA (Table 2).

Most cells use the oxidation potential of $\mathrm{O}_{2}$ to enormous advantage in the cytochrome system, where reduction to water is used to generate ATP (86). However, the cytochrome system may have evolved mainly as a means for the detoxification of oxygen, a mechanism that was only secondarily exploited for its energy-producing capacity through selective pressures for more efficient metabolism of scarce organic carbon substrates.

Under normal conditions, most $\mathrm{O}_{2}$ in biological systems undergoes tetravalent reduction by efficient intracellular systems such as the cytochrome complex (87). However, $1 \%$ to $2 \%$ of $\mathrm{O}_{2}$ "leaks" from this pathway to undergo univalent reduction, as illustrated in Figure 2 (88). As can be seen in this figure, the univalent pathway results in the formation of $\mathrm{O}_{2}$. (superoxide anion or superoxide radical), $\mathrm{H}_{2} \mathrm{O}_{2}$ (hydrogen peroxide) and $\mathrm{OH} \cdot$ (hydroxyl radical) as the intermediates. These intermediates are too reactive to be tolerated in living tissue, and their removal and control has been the challenge of all aerobic organisms since the first appearance of $\mathrm{O}_{2}$ in the atmosphere.

The protective and controlling mechanisms can be divided into enzymatic, hydrophobic, hydrophilic and structural groups, as shown in Table 3 (84). In Figure 2, the enzymatic bypass mechanisms are depicted in relation to the univalent pathway.

Oxygen-derived Free Radicals and Hepatic Reperfusion Injury. Various sources of oxygen-derived free radicals are suggested. According to McCord (60), the major source of the oxygen-derived free radicals is $\mathrm{XO}$ (89). This enzyme - of which rich sources are present in the intestine, lung and liver - is synthesized in the form of XD. This form accounts for about $90 \%$ of the total activity in healthy tissue. XD does not produce oxygenderived free radicals, but can reduce $\mathrm{NAD}^{+}$to form uric acid from xanthine:

$$
\text { Xanthine }+\mathrm{H}_{2} \mathrm{O}+\mathrm{NAD}^{+}-(\mathrm{XD}) \rightarrow \text { Uric acid }+\mathrm{NADH}+\mathrm{H}^{+}
$$


TABLE 3. Classification of protective controlling mechanisms of oxygen-derived free radicals

\begin{tabular}{ll}
\hline Main group & \multicolumn{1}{c}{ Example } \\
\hline Enzymatic & $\begin{array}{c}\text { Superoxide dismutase, catalase and perox- } \\
\text { idase (cytochrome oxidase) } \\
\text { - } \text {-Tocopherol (vitamin E) and } \beta \text {-carotenes } \\
\text { in cellular membranes, glutathione per- } \\
\text { oxidase }\end{array}$ \\
Hydrophobic & $\begin{array}{c}\text { Ascorbic acid and cysteine, reduced glu- } \\
\text { tathione, ceruloplasmin and transferrin } \\
\text { in plasma }\end{array}$ \\
Cholesterol in biomembranes, localization \\
of certain reactions to peroxisomes and \\
mitochondria
\end{tabular}

XO can use $\mathrm{O}_{2}$ instead of $\mathrm{NAD}^{+}$, producing $\mathrm{O}_{2}^{-}$(or $\mathrm{H}_{2} \mathrm{O}_{2}$ or both) as follows:

Xanthine $+\mathrm{H}_{2} \mathrm{O}+2 \mathrm{O}_{2} \quad(\mathrm{XO}) \rightarrow$ uric acid $+2 \mathrm{O}_{2} \quad+2 \mathrm{H}$.

As hypothesized by McCord (60), the elevated cytosolic $\mathrm{Ca}^{2+}$ concentration, which results from ischemia as described above, activates a protease capable of converting $\mathrm{XD}$ to $\mathrm{XO}$. Concomitantly, the consumption of the residual amounts of ATP results in an elevated concentration of AMP, which is further catabolized to adenosine, inosine and then hypoxanthine. This hypoxanthine and xanthine serve as oxidizable substrates for $\mathrm{XD}$ or XO. Thus during anoxia a new enzyme activity appears along with one of its two required substrates. During anoxia, however, almost no oxygen-derived free radicals are produced because the remaining substrate required for XO activity $-\mathrm{O}_{2}-$ is absent. During reperfusion of the tissue, $\mathrm{O}_{2}$ is suddenly abundant. This results in a burst of oxygen-derived free radicals and $\mathrm{H}_{2} \mathrm{O}_{2}$ production. If the tissue is anoxic for even a short period, a rapid increase in the amount of XO activity occurs. In the liver, XO content doubles after about 30 min (this is about the same in spleen, lung and kidney) (60). In the heart, the same increase requires only $8 \mathrm{~min}$ of nonperfusion. Skeletal muscle is unique in this respect because $\mathrm{XD}$ does not convert to XO during nonperfusion; this correlates well with the clinically observable resistance of skeletal muscle to ischemic injury.

In contradiction to this mechanism of generation of oxygen-derived free radicals, Metzger et al. (90) found no evidence for a role of XO in hepatic reperfusion injury. In a model of reperfusion after a period of warm ischemia of the rat liver, they found no effect of allopurinol (an inhibitor of xanthine oxidase) and demonstrated the oxidant stress not to be maximal when the available concentration of substrates for XO is highest (i.e., at the onset of reperfusion). This study, however, used a model of warm ischemia in which the initiation of oxygen-derived free radicals may be quite dissimilar to the cold-ischemia situation. Indeed, Marzi et al. (91) observed a rapid accumulation of xanthine and hypo- xanthine after simple cold storage of the rat liver, which is consistent with the hypothesis that $\mathrm{XO}$ generates free radicals during reperfusion.

Another possible source of oxygen-derived free radicals may be the activation of leukocytes and resident macrophages $(90,92)$. These cells can generate large amounts of toxic mediators such as oxygen-derived free radicals, leukotrienes and proteases. This activation may be induced by surface receptors of endothelial cells, exposed by anoxic damage (as has been demonstrated in other models) (91, 93). In this case the oxygen-derived free radicals are probably released by membraneassociated enzymes such as lipoxygenase and cyclooxygenase, which are active in arachidonic acid metabolism (85).

What has not been clarified is why the naturally occurring scavenging mechanisms - in particular superoxide dismutase (SOD) - are unable to dismutate the oxygen-derived free radicals at reperfusion. However, because no need exists for these during anoxia, they may be chemically altered during this period. Corresponding with this assumption, decreased SOD activity has been measured during hypoxia $(94,95)$. The simplest explanation, however, is that a relative overload of oxygenderived free radicals arises at reperfusion. The relatively high oxygen tensions in the situation of inadequately functioning mitochondria, damaged during the ischemic period, and decreased scavenging mechanisms may result in a high free radical load, culminating in further membrane damage and cell death (84).

It appears that oxygen-derived free radicals play a major role in the development of reperfusion injury. The actual source of the toxic oxygen species, however, is not known. On the basis of currently available data it may be hypothesized that - at reperfusion after warm ischemia - the main source of oxygen-derived free radicals is the activation of leukocytes and macrophages to injure the sinusoidal lining cells. This is in agreement with the assumption that direct injury to the cytoskeleton and the resulting alteration of surface receptors are the most important consequences of anoxic damage. Reperfusion after cold ischemia probably induces an overload of oxygen-derived free radicals mainly produced by $X O$. In the latter mechanism, increased cytosolic $\mathrm{Ca}^{2+}$ levels during anoxia may play an important role. The potential mechanisms of anoxic and reperfusion damage are depicted in Figure 3.

\section{CYTOPROTECTIVE COMPOUNDS IN LIVER PRESERVATION}

The term "cytoprotection" stems from the observation that prostaglandins could protect epithelial cells of hollow gastrointestinal viscera against various ulcerogenic agents that would otherwise produce cell damage and necrosis (96). This advantageous effect appeared not to be limited to the digestive tract (97). To date, the concept of hepatocytoprotection represents the beneficial property of any agent preventing harvest injury. In the next section, some of the various drugs (Table 4) are described and considerations of the working mechanism 


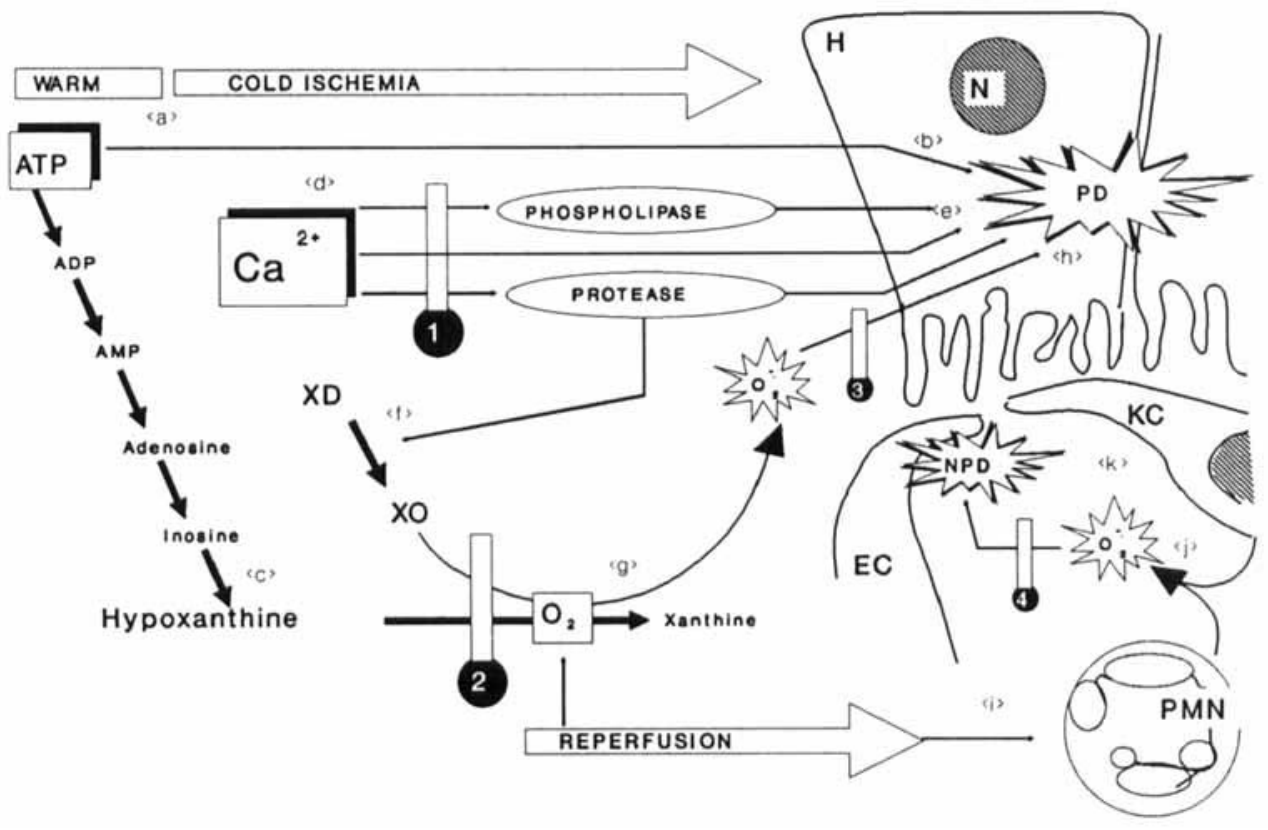

FIG. 3. Hypothesized mechanism of harvest injury. Warm ischemia (and cold ischemia at a lower rate) causes depletion of ATP (a). This induces damage to the energy-requiring cytoskeleton of the hepatocyte (b) (and to the nonparenchymal cells; not shown). ATP is broken down stepwise, leading to an accumulation of hypoxanthine (c). With longer-lasting cold ischemia, $\mathrm{Ca}^{2}$ a accumulates (d). Directly, but also by activation of various phospholipases and proteases, this leads to cytoskeleton damage in the hepatocyte (e) (and to the nonparenchymal cells; not shown). Simultaneously, this activation of proteases induces a rapid conversion of XD to XO oxidase ( $\mathrm{X}$ ). Consequently, both activated enzyme (XO) and its substrate (hypoxanthine) are abundant. At reperfusion, oxygen is supplied in excess, leading to a burst of intracellular oxygen-derived free radicals ( $\mathrm{g}$ ), which also adds to the parenchymal damage (h). At reperfusion, polymorphonuclear leukocytes (i) and Kupffer cells are activated by tissue antigens of endothelial cells (which have come to expression by the preceding anoxic injury) to produce extracellular oxygen-derived free radicals and other toxic mediators (j). This causes escalation of nonparenchymal damage (k). $H=$ hepatocyte; $N=$ nucleus; $E C=$ endothelial cell; $K C=$ Kupffer cell; $P M N=$ polymorphonuclear leukocyte; $P D=$ parenchymal damage; $N P D=$ nonparenchymal damage; $1=\mathrm{Ca}^{2+}$ entry-blockers and cAMP-related mechanisms; 2 = direct prevention of oxygen-derived free radical generation; 3 = scavengers of intracellular oxygen-derived free radicals; and $4=$ scavengers of extracellular oxygen-derived free radicals.

are given, arranged as to the composition of warm and cold ischemic and anoxic and reperfusion damage to hepatocytes and endothelial cells, as described above and illustrated in Figure 3.

Calcium-and cAMP-related Mechanisms. Agents in this category act by reducing the intracellular $\mathrm{Ca}^{2+}$ accumulation induced by anoxia as delineated above. As already pointed out, the interrelationship of $\mathrm{Ca}^{2+}$ and cAMP is not understood. However, cAMP has been reported to produce an immediate and transient efflux of $\mathrm{Ca}^{2+}$ in perfused livers of rats (98). Hypothetically, this is caused by the inhibition of the generation of the $\mathrm{Ca}^{2+}$-calmodulin complex (Fig. 4). This results in free calmodulin, which facilitates the extrusion of the simultaneously released $\mathrm{Ca}^{2+}$. On the other hand, cAMP may also directly promote $\mathrm{Ca}^{2+}$ efflux. Calmodulin and cAMP are believed to act by the $\mathrm{Ca}^{2+}$-specific ATPase (99). Therefore, drugs believed to invoke cAMP production are included in this category also.

$\mathrm{Ca}^{2+}$ entry blockers such as verapamil bind to membrane structures responsible for the "slow channels." The presumed efficacy of these drugs, however, may be questioned because no potential gated "slow $\mathrm{Ca}^{2+}$ channels" have been described in nonexcitable tissues (50). Still, diltiazem has been demonstrated to have a protective effect in liver ischemia and reperfusion in pigs (100), and verapamil has been shown to be useful in combination with prostaglandin $I_{2}$ after 24-hr liver preservation (101) and to increase the tolerance of the rat liver to ischemia (102). This seeming contradiction may be explained by the fact that calcium blockers not only change plasma membrane $\mathrm{Ca}^{2+}$ transport but may also protect cells by inhibiting $\mathrm{Ca}^{2+}$ mobilization from intracellular sources (103).

Isoproterenol has a $\beta_{2}$-mimetic effect and activates adenylate cyclase, increasing cAMP (104). Lambotte et al. (105) have demonstrated the protective effect of isoproterenol in orthotopic canine liver transplantation.

Chlorpromazine is an antagonist of histamine, $\alpha$-adrenergic and dopamine receptors. It is, however, also suggested to act by $\mathrm{Ca}^{2+}$-calmodulin antagonism (106), and it has been shown to suppress the activity of phospholipases (107) and to stabilize lysosomes (108). Nonetheless, the efficacy of chlorpromazine is controversial $(105,109,110)$.

Dibucaine inhibits phospholipase $\mathrm{A}_{2}$. Theoretically, it may therefore prevent injury by inhibiting the $\mathrm{Ca}^{2+}$. related activation of phospholipase $A_{2}$. Its cytoprotective effects are a matter of controversy $(111,112)$.

Aprotinin is a naturally occurring inhibitor of proteolytic enzymes; it therefore may possess cytoprotective 
Table 4. Agents used to prevent oxygen-derived free radical-induced harvest injury

Related to calcium or cAMP
Calcium entry-blockers
Isoproterenol
Chlorpromazine
Dibucaine
Aprotinin
Adrenocorticoids
Prostaglandins
Direct prevention of $\mathrm{O}_{2}:$ formation
Allopurinol
Oxygen-derived free radical scavengers
Chelators
Mannitol and DMSO
SOD
Unknown
Chloroquine
Coenzyme $\mathrm{Q}_{10}$
Tris-hydroxymethyl-amino-methane
Phenoxybenzamin

effects caused by inhibition of $\mathrm{Ca}^{2+}$-related activation of proteases (113).

Conventionally, the cytoprotective effects of corticosteroids are attributed to their membrane-stabilizing properties (see below) (114). However, an enormous variety of mechanisms of action are ascribed to these drugs, many theoretical. The antiphlogistic effect, for which corticosteroids are famous, is probably caused by inhibition of the arachidonic acid production required to activate the enzymatic pathway of inflammation (prostaglandins and leukotrienes). This is achieved as follows: corticosteroids stimulate the synthesis of a protein called lipomodulin, which in its turn inhibits the activity of phospholipases (note the resemblance with calmodulin), preventing the initial release of arachidonic acid (115). The role of corticosteroids in preventing harvest injury remains to be established.

In the $1930 \mathrm{~s}$, three laboratories independently described a uterine smooth muscle-contracting activity deriving from semen. It was termed prostaglandin because it was assumed to originate in the prostate gland. The first two were called prostaglandin $\mathrm{E}$ and $\mathrm{F}$, with respect to their solvent partitioning into ether and phosphate (fosfat in Swedish). A prostaglandin (PG) is a 20-carbon fatty acid that contains a five-carbon ring. Nine groups of PGs have been identified and assigned the letter designations $\mathrm{A}$ through $\mathrm{I}$, followed by a subscript denoting the number of carbon-carbon double bonds outside the ring. The latest-discovered $\mathrm{PG}, \mathrm{PGI}_{2}$, has been shown to possess a variety of interesting biological activities, including inhibition of platelet aggregation, vasodilatation, stabilization of lysosomal membranes and increase of blood flow to the splanchnic region (116-118). All these effects, which are also attributed to $\mathrm{PGE}_{1}$, may play a role in the hepatocytoprotective properties of PGs. Araki and Lefer (119), however, convincingly showed that the stabilization of lysosomal membranes by $\mathrm{PGI}_{2}$ is probably the most prominent mechanism. This stabilization of lysosomal membranes, however, is no more than a description of what can be demonstrated when cells are protected by mechanisms - still to be elucidated - resulting in diminished cell death as measured by the reduced appearance of lysosomal enzymes. Therefore other theories of the mechanism of action of $P G s$ are required. In this respect it is proposed that the cytoprotective action of PGs is related to the well-established mechanism of platelet aggregation inhibition: $\mathrm{PGI}_{2}$ and $\mathrm{PGE}_{1}$ stimulate platelet adenyl cyclase, leading to an increase in platelet cAMP (117). As shown above, cAMP may play a key role in preventing liver harvest injury in an intricate interaction with $\mathrm{Ca}^{2+}$ and calmodulin (120). The fact that PGE, has been shown to inhibit adenyl cyclase in fat cells demonstrates that PGs may have opposite effects in different tissues (121).

The hepatocytoprotective properties of the $\mathrm{PGI}_{2}$ and $\mathrm{PGE}_{1}$ has been reported by various authors, and their efficacy is reproducible in a variety of models $(1,100$, 122-125). Of particular interest in this respect is the report of Araki and Lefer (119), who demonstrated protection of hypoxia-induced liver damage in an isolated perfused cat liver model using $\mathrm{PGI}_{2}$. Using $\mathrm{PGI}_{2}$ as additive to the preservation fluids, a significant improvement of animal and graft survival and graft function was obtained after orthotopic liver transplantation in dogs and pigs with liver grafts stored for 24 and $48 \mathrm{hr}(101,126,127)$. In human liver transplantation, $\mathrm{PGE}_{1}$ has been shown to significantly improve graft function and decrease graft damage (128). In addition, $\mathrm{PGE}_{1}$ has been useful in treating fulminant hepatic failure (129) and in treating primary graft nonfunction (130).

Direct Prevention of $\mathrm{O}_{2}^{-}$Formation. Allopurinol is known to be an XO inhibitor because it decreases the breakdown of xanthine and hypoxanthine to urate in gouty arthritis. Several studies have shown a protective effect of allopurinol against ischemia-induced renal injury (131). Initially, these beneficial effects were thought to be established by preventing the loss of purine bases from the anoxic cell. Once degradation of a nucleotide has proceeded beyond the xanthinehypoxanthine level to uric acid, there is no way back to generate ATP. At present, however, it is generally accepted that allopurinol owes its beneficial effect in ischemia to prevention of generation of oxygen-derived free radicals (132). In addition, it is postulated that allopurinol has radical-scavenging properties (133). Allopurinol has been used in liver ischemia with contradictory results $(30,90,134)$.

Oxygen-derived Free Radical Scavengers. As already mentioned, physiologically occurring oxygen-derived free radical scavengers are abundant in a variety of human and animal tissues; this suggests that this enzyme plays a significant, even vital, role in protecting the organism against the damage of $\mathrm{O}_{2}^{-}$.

In particular, SOD (135) has been studied extensively (82). With respect to liver preservation, it has been shown experimentally that SOD is effective in dimin- 


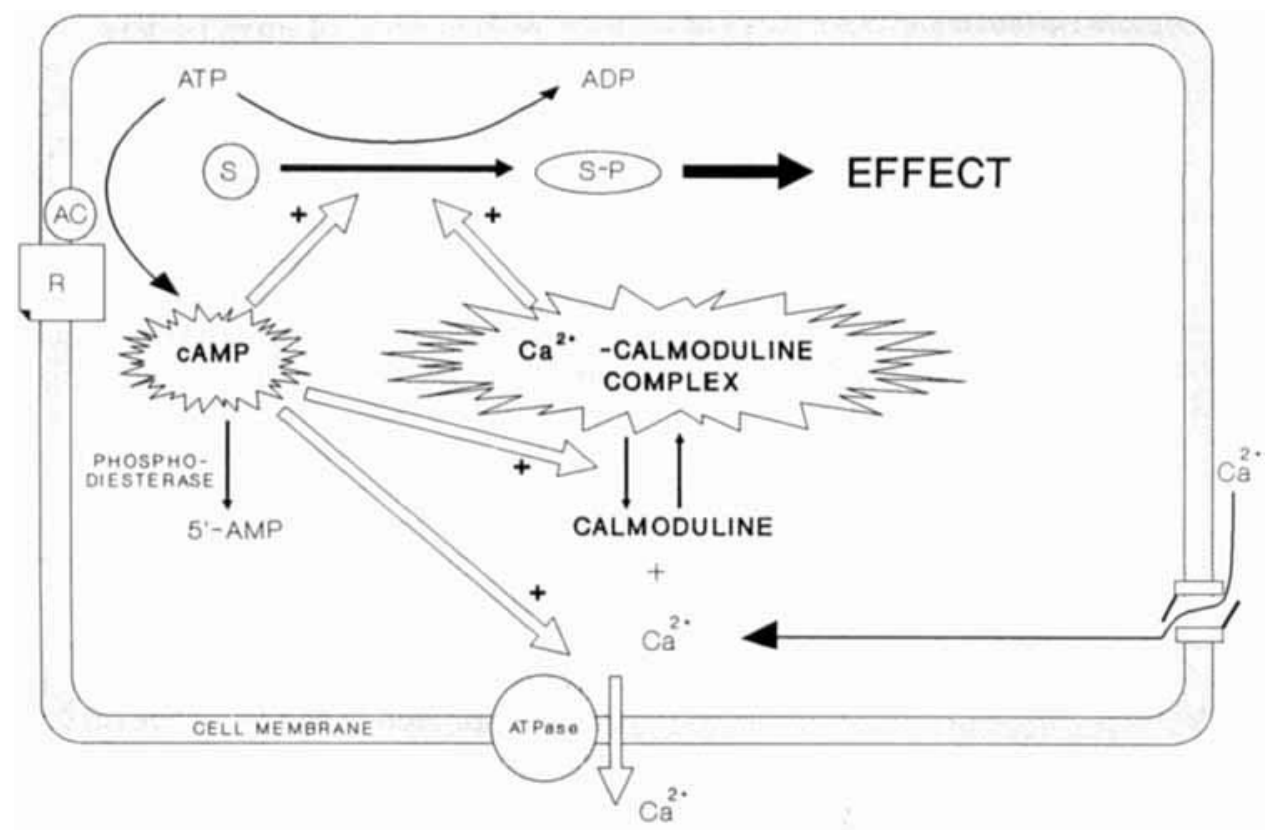

FIG. 4. Schematic diagram depicting the hypothesized role of cAMP and the $\mathrm{Ca}^{2+}$-calmodulin complex as intracellular second messengers. When a hormone binds to its membrane receptor $(R)$, this activates adenylate cyclase $(A C)$. cAMP synthesized by the AC diffuses through the cytoplasm and activates the phosphorylation of specific substrate proteins (S), usually enzymes. Phosphorylation activates these enzymes, denoted as $S \sim P$, which in turn produce the cell-specific effects. The $\mathrm{Ca}^{2+}$-calmodulin complex has a similar pathway for inducing certain effects. Furthermore, cAMP inhibits the formation of the $\mathrm{Ca}^{2+}$-calmodulin complex and probably facilitates $\mathrm{Ca}^{2+} \mathrm{extrusion}^{2} \mathrm{Ca}^{2+}-\mathrm{ATPase}^{2}$ in the cell membrane.

ishing the extent of harvest injury $(82,136)$. These results, however, are still subject of discussion: Southard et al. (137) questioned the potential effect of oxygen-derived free radical scavengers in liver preservation in a study in which they measured XO and SOD activity of liver and kidney tissue of rats, dogs and humans. In the human, the highest concentrations of SOD were found in the intestine and liver. Nevertheless, no data exist on the activity of endogenous scavenger enzymes after long-term cold storage of these organs. It is conceivable that these enzymes are chemically altered, since there is no or a limited need for these scavenging mechanisms during anoxia, because free radical generation is very limited in the absence of oxygen (84). Others suggest that exogenous SOD is not likely to enter cells to detoxify $\mathrm{O}_{2}-$ generated in hepatocytes (138). For that reason, the effects of exogenous SOD may be confined to prevention of damage caused by extracellularly generated $\mathrm{O}_{2}-$ (leukocytes).

In addition, various nonphysiological agents have been shown to have scavenging properties. Chelators block $\mathrm{Fe}^{2+}$-related propagation reactions of oxygenderived free radicals, and mannitol and dimethylnitrosamine are known hydroxyl radical scavengers. Their potential beneficial effects in liver preservation are open to speculation.

Unknown Mechanisms of Action. Because the mechanisms of the previously mentioned agents are mainly hypothetical, no more than descriptions of the chemical properties are available of the following drugs, without an understanding of the relationship with the suggested efficacy in preventing harvest injury.

Coenzyme $\mathbf{Q}_{10}$ is a quinone derivate (with 10 isoprene units) and is a highly mobile carrier of electrons between the flavoproteins and the cytochromes (b-cl-c-a/a3) of the electron-transport chain in mitochondria. It may act as an antioxidant in the protection of oxygen-derived free radical-induced damage (139-141).

Phenoxybenzamin blocks receptors for histamine (1), acetylcholine and serotonin. It has been shown to be useful in kidney preservation, but its value in liver preservation is a matter of controversy $(2,109,111)$.

Corticosteroids are mentioned again in this category to stress the fact that the "lysosomal stabilization" is not what can be called a biochemical mechanism of action and that the real mechanism of action of corticosteroids is still to be elucidated. The latter accounts for all other agents with no other interpretation of their effects than "stabilization of lysosomal membranes."

\section{UW SOLUTION}

By reconsidering the components of cold-storage solutions for organ preservation, a new solution was developed at the University of Wisconsin by a pioneer in the field of organ transplantation, Folkert Belzer. In 1987, Wahlberg et al. (142) reported the first results of 72-hr preservation of the canine pancreas with the so called UW solution. Soon, successful 24- to $48-\mathrm{hr}$ simple cold storage of the canine liver was described (6). In 
TaBle 5. Composition of and rationale for ingredients of UW solution

\begin{tabular}{|c|c|c|}
\hline Substance & Amount/1 L & Rationale \\
\hline \multicolumn{3}{|l|}{ Basic components } \\
\hline $\mathrm{K}$-lactobionate & $100 \mathrm{mmol}$ & Barrier \\
\hline $\mathrm{NaKH}_{2} \mathrm{PO} 4$ & $25 \mathrm{mmol}$ & Buffer \\
\hline $\mathrm{MgSO}_{4}$ & $5 \mathrm{mmol}$ & $\begin{array}{l}\text { Membrane stabili- } \\
\text { zation }\end{array}$ \\
\hline Raffinose & $30 \mathrm{mmol}$ & Oncotic support \\
\hline \multicolumn{3}{|l|}{ Additives } \\
\hline Hydroxyethyl starch & $50 \mathrm{gm}$ & Colloid \\
\hline Allopurinol & $1 \mathrm{mmol}$ & XO inhibitor \\
\hline Glutathione & $3 \mathrm{mmol}$ & Scavenger \\
\hline Adenosine & $5 \mathrm{mmol}$ & ATP precursor \\
\hline Insulin & $100 \mathrm{IU}$ & \\
\hline Penicillin & $40 \mathrm{IU}$ & \\
\hline Dexamethasone & $8 \mathrm{mg}$ & \\
\hline
\end{tabular}

The solution is brought to $\mathrm{pH} 7.4$ at room temperature with $\mathrm{NaOH}$. Final osmolality is $320 \mathrm{mOsm} / \mathrm{L}$.

March 1988, Kalayoglu and co-workers (143) reported the first clinical use of this new preservation solution in liver transplantation. Tolerance of cold ischemia by the human liver appeared to be significantly improved from $8 \mathrm{hr}$ or less with Collins' solution to more than $10 \mathrm{hr}$ (range $=11$ to $20 \mathrm{hr}$ ) in nine cases.

The key to the success of this advance lay in the approach of these investigators to organ preservation because they recognized the different metabolic aspects of the various organs. Because the success of cold storage preservation is primarily related to the prevention of tissue edema, the selection of an organ-specific was the most important aspect (143).

Besides the reduction of cellular swelling, the following requirements for the new solution were defined: prevention of intracellular acidosis, prevention of expansion of the interstitial space during the flush-out period, prevention of injury from oxygen-derived free radicals and availability of substrates for regenerating high-energy phosphate compounds during reperfusion. Table 5 shows the composition of the UW solution. The solution is based on lactobionate and raffinose as impermeants to suppress hypothermia-induced tissue swelling, replacing glucose and mannitol in Collins' solution and hypertonic citrate, respectively. The latter sugars are effective as impermeants in the kidney, but the liver shows free permeability to these small carbohydrates, rendering them unsuitable as impermeants. Phosphate is included in the solution as a buffer to prevent tissue acidosis, induced by the increased rate of anaerobic metabolism in the ischemic cells. Hydroxyethyl starch is added as a colloid for oncotic support during the flush-out period. Allopurinol and reduced glutathione are included as free radical scavengers and magnesium sulfate is used for its presumed membranestabilizing properties. Adenosine is added as a precursor for ATP resynthesis.

Obviously some agents are added for theoretical reasons only. Although results with $\mathrm{UW}$ solution are better than any obtained to date with any technique of liver preservation, the composition is somewhat ambiguous with respect to the role of oxygen-derived free radicals in harvest injury. Adhering to the hypothesis that oxygen-derived free radicals are responsible for most harvest injuries, it is apparent that adenosine could serve as a substrate for XO. In that way it could stimulate the formation of free radicals. Belzer and Southard (5) do recognize this problem in stating that omitting adenosine from the UW solution may be necessary when using it in lung or intestine preservation. The fact that they do include adenosine in the liver storage solution is based on earlier studies on the $\mathrm{XO}$ and SOD activity in the liver and kidney (137). These observations suggested that oxygen-derived free radicals may be of little significance in human livers and kidneys. Still, allopurinol is added as a free radical scavenger.

Another important consideration in this multifactorial approach is the fact that no attempt was made to gain an increase in cellular cAMP, whereas theoretical propositions and experimental evidence are accumulating to show that this could be an important early step in the prevention of intracellular $\mathrm{Ca}^{2+}$ accumulation, as shown above (120). Therefore, prostaglandins may theoretically be a valuable additive to the UW solution.

It is remarkable how little is known about the exact role of the various additives of the UW solution in preventing harvest injury. Therefore, in trying to define the relevance of the various components of the UW solution empirically, the omission of several additives has been investigated. Recently Jamieson et al. (144) demonstrated that raffinose, lactobionate and gluthatione could not be omitted. However, in their experiment, after $48 \mathrm{hr}$ of ice storage rabbit livers were reperfused ex vivo, and organ transplantation was not performed to confirm graft viability. Except for the finding that colloid improved the rheological properties of the UW solution, none of the additives besides the basic components improved preservation in kidney transplantation (145).

Another interesting subject is the development of variants of the UW solution in which high $\mathrm{K}^{+}$concentration is replaced by high $\mathrm{Na}^{+}$concentration. This has a number of potential advantages, one being the fact that solutions containing high $\mathrm{K}^{+}$levels (UW solution) can induce serious endothelial damage. Indeed, the high- $\mathrm{K}^{+}$ UW version appeared to be equally or slightly more effective $(146,147)$.

\section{CONCLUSIONS AND FUTURE DIRECTIONS}

With improving technical proficiency and the introduction of cyclosporine, liver transplantation has evolved to a well-established treatment of end-stage cirrhosis. Extensive research resulted in a substantial advance in the most prominent feature of liver transplantation at the moment: organ preservation. Because the liver is threatened by multiple important hazards at organ procurement and during subsequent storage and reperfusion, a multifactorial approach was shown to be essential in the development of an effective cold storage 
solution and safely preserving liver grafts over a period long enough to perform liver transplantation as an elective procedure.

Many interesting aspects of organ preservation will be the subject of further investigation in the future. The combination of cold storage - to harvest and to transport the donor organ-and subsequent placement on a perfusion machine once it arrives in the actual transplantation center-to enable selection of the most suitable recipient-is one of the promising modifications. It has already been reported to provide successful 5-day preservation of the canine kidney (148).

Another major topic in the near future will be assessment of graft viability. Nuclear magnetic resonance imaging (149) and other methods to measure the loss of liver nucleotides and energy charge (150-153) and biochemical assays of the liver perfusate (67) may provide sensitive markers to predict graft viability before transplantation.

Future studies of other mechanisms of harvest injury, incorporating the above-mentioned and/or other additives to the preservation solution, will be necessary to further prolong the safe storage period. This could permit donor-recipient tissue-matching and reduce the emergency aspects of liver transplantation.

\section{REFERENCES}

1. Tamaki T, Okouchi Y, Kozaki M, Kawamura A, Uchino J, Pegg DE. Hypothermic preservation of the rat liver assessed by orthotopic transplantation. III. Improved functional recovery with isotonic citrate solution and a stable prostacyclin analogue. Transplantation 1988;46:626-628.

2. Collins GM, Bravo-Shugarman M, Terasaki PI. Kidney preservation for transportation: initial perfusion and 30 hours' ice storage. Lancet 1969;2:1219-1222.

3. Bismuth H, Castaing D, Ericzon BG, Otte JB, Rolles K, Ringe B, Sloof M. Hepatic transplantation in Europe: first report of the European liver transplant registry. Lancet 1987;2:674-676.

4. Belzer FO. Principles of organ preservation. Transplant Proc 1988;20:925-927.

5. Belzer FO, Southard JH. Principles of solid-organ preservation by cold storage. Transplantation 1988;45:673-676.

6. Jamieson NV, Sundberg R, Lindell S, Claesson K, Moen J, Vreugdenhil PK, Wight DGD, et al. Preservation of the canine liver for 24-48 hours using simple cold storage with UW solution. Transplantation 1988;46:517-522.

7. Todo S, Nery J, Yanaga K, Podesta L, Gordon RD, Starzl TE. Extended preservation of human liver grafts with UW solution. JAMA 1989;261:711-714.

8. Welch CS. A note on the transplantation of the whole liver in dogs. Transplant Bull 1955;2:54-56.

9. Goodrich EO, Welch HF, Nelson JA, Beecher TS, Welch CS. Homotransplantation of the canine liver. Surgery 1956;39: 244-251

10. Starzl TE, Kaupp HA, Brock DR, Lazarus RE, Johnson RV. Reconstructive problems in canine liver homotransplantation with special reference to the postoperative role of hepatic venous flow. Surg Gyn Obstet 1960;111:733-743.

11. Sicular A, Moore FD. A study of the post mortem survival of tissues. J Surg Res 1961;1:16-21.

12. Starzl TE. Experience in renal transplantation. Philadelphia: W.B. Saunders Co., 1964

13. Calne RY, Pegg DE, Pryse-Davies J, Brown FL. Renal preservation by ice-cooling: an experimental study relating to kidney transplantation from cadavers. Br Med J 1963;2:651-655.

14. Marchioro TL, Huntley RT, Waddell WR, Starzl TE. The use of extracorporeal perfusion for obtaining post mortem grafts. Surgery 1963;54:900-903.

15. Mikaeloff P, Kestens PJ, Dureau G, Rassat JP. Transplantation orthotopique du foie chez le chien après conservation de l'organe par perfusion. Mem Acad Chir Par 1965;91:711-724.

16. Kestens PJ, McDermott WV Jr. Perfusion and replacement of the canine liver. Surgery 1961;50:196-199.

17. Brown H, Patel J, Blair DW, Brown ME. Biochemical studies with preserved transplanted canine liver. J Am M Ass 1966;196: 775-777.

18. Moss GS, Reed P, Riddell AG. Observations on the effects of glycerol on the cold storage of the canine liver. J Surg Res 1966;6:147.

19. Belzer FO, Ashby BS, Dunphy JE. 24-Hour and 72-hour preservation of canine kidneys. Lancet 1967;2:536-539.

20. Slapak M, Wigmore RA, MacLean LD. Twenty-four hour liver preservation by the use of continuous pulsatile perfusion and hyperbaric oxygen. Transplantation 1967;5:1154-1158.

21. Starzl TE, Marchioro TL, von Kaulla KN, Herman G. Homotransplantation of the liver in humans. Surg Gyn Obstet 1963;117:659-676.

22. Starzl TE, Marchioro TL, Porter KA. Advances in surgery. Chicago: Year Book Medical Publishers, 1966:295-312.

23. Schalm SW, Terpstra JL, Drayer B, van den Berg C, Veltkamp JJ. A simple method for short-term preservation of a liver homograft. Transplantation 1969;8:877-881.

24. Wall WJ, Calne RY, Herbertson BM, Baker PG, Smith DP, Underwood J, Kostakis A, et al. Simple hypothermic preservation for transporting human livers long distances for transplantation: report of 12 cases. Transplantation 1977;23:210-216.

25. Benichou J, Halgrimson CG, Weil R, Koep LJ, Starzl TE. Canine and human liver preservation for 6 to $18 \mathrm{hr}$ by cold infusion. Transplantation 1977;24:407-411.

26. Brettschneider L, Daloze PM, Huguet C, Porter KA, Groth CG, Kashiwagi N, Hutchison DE, et al. The use of combined preservation techniques for extended storage of orthotopic liver homografts. Surg Gyn Obstet 1968;126:263-274.

27. Belzer FO, May R, Berry MN, Lee JC. Short term preservation of porcine livers. J Surg Res 1970;10:55-61.

28. Perkins HA, May RE, Belzer FO. Cause of abnormal bleeding after transplantation of pig liver stored by a perfusion technique. Arch Surg 1970;101:62-68.

29. Calne RY, Dunn DC, Herbertson BM, Gordon EM, BitterSuermann H, Robson AJ, MacDonald AS, et al. Liver preservation by single passage hypothermic "squirt" perfusion. Br Med J 1972;4:142-144.

30. Toledo-Pereyra LH, Simmons RL, Najarian JS. Factors determining successful liver preservation for transplantation. Ann Surg 1975;181:289-298.

31. Petrie CR, Woods JE. Successful 24-hour preservation of the canine liver. Arch Surg 1973;107:461-464.

32. Sung DTW, Woods JE. Forty-eight-hour preservation of the canine liver. Ann Surg 1974;179:422-426.

33. Tamaki T, Kamada N, Wight DG, Pegg DE. Successful 48-hour preservation of the rat liver by continuous hypothermic perfusion with haemaccel-isotonic citrate solution. Transplantation 1987 ; 43:468-471

34. Nakajima I, Fuchinoue S, Teraoka S, Tojinbara T, Fujikawa $H$, Kawai $\mathrm{T}$, Honda $\mathrm{H}$, et al. Long-term liver preservation using artificial blood substitute. Transplant Proc 1989;21:1314-1315.

35. Abouna GM, Koo CG, Howanitz LF, Ancarani E, Porter KA. Successful orthotopic liver transplantation after preservation by simple hypothermia. Transplant Proc 1971;3:650-653.

36. Spilg H, Uys CJ, Hickman R, Saunders SJ, Terblanche J. Successful liver transplantation after storage for 6-8 hours, using a simple hypothermic immersion technique. Transplantation 1971;11:457-460.

37. Mieny CJ, Myburgh JA. Successful 20-hr preservation of the primate liver by simple cooling. Transplantation 1971;11: $495-496$.

38. Dreikorn K, Horsch R, Rohl L. 48 to 96 hour preservation of canine kidneys by initial perfusion and hypothermic storage using Euro Collins solution. Eur Urol 1980;6:221-224. 
39. Toledo-Pereyra LH, Chee M, Lillehei C, Condie RM. Liver preservation by cold storage with hyperosmolar solutions for twenty-four hours. Cryobiology 1979;16:43-49.

40. Sacks SA, Petritsch PH, Kaufman JJ. Canine kidney preservation using a new perfusate. Lancet 1973;1:1024-1028.

41. Tamaki T, Kamada N, Pegg DE. Hypothermic preservation of the rat liver assessed by orthotopic transplantation: a comparison of flush solutions. Transplantation 1986;41:396-397.

42. Farber JL, Young EE. Accelerated phospholipid degradation in anoxic rat hepatocytes. Arch Biochem Biophys 1981;211: $312-320$

43. Lemasters JJ, DiGuiseppi J, Nieminen A, Herman B. Blebbing, free $\mathrm{Ca} 2+$ and mitochondrial membrane potential preceding cell death in hepatocytes. Nature 1987;325:78-81.

44. MacKnight ADC, Leaf A. Regulation of cellular volume. Physiol Rev 1977;57:510-573.

45. Glynn IM. Membrane adenosine triphosphatase and cation transport. Br Med Bull 1968;24:165.

46. Skou JC. Enzymatic basis for active transport of $\mathrm{Na}+$ and $\mathrm{K}+$ across cell membrane. Physiol Rev 1965;45:596.

47. Martin DR, Scott DF, Downes GL, Belzer FO. Primary cause of unsuccessful liver and heart transplantation: cold sensitivity of the ATPase system. Ann Surg 1972;175:111-117.

48. Schanne FAX, Kane AB, Young EE, Farber JL. Calcium dependence of toxic cell death: a final common pathway. Science 1979;206:700-702

49. Ringer $S$. Regarding the action of hydrate of soda, hydrate of ammonia, and hydrate of potassium on the ventricle of the frog's heart. J Physiol 1883;3:195-202.

50. Carafoli E. Membrane transport and the regulation of the cell calcium levels. In: Cowley RA, Trump BF, eds. Pathophysiology of shock, anoxia and ischemia. Baltimore: Williams \& Wilkins, 1982:95-111.

51. Cheung WY. Phosphodiesterase: pronounced stimulation by snake venom. Biochem Biophys Res Commun 1967;29:478-482.

52. Levine RA. The role of cyclic AMP in hepatic and gastrointestinal function. Gastroenterology 1970;59:280-300.

53. Cotteril LA, Gower JD, Fuller BJ, Green CJ. Oxidative damage to kidney membranes during cold ischemia: evidence of a role for calcium. Transplantation 1989;48:745-751.

54. Snowdowne KW, Freudenrich CC, Borle AB. The effect of anoxia on cytosolic free calcium, calcium fluxes and cellular ATP levels in cultured kidney cells. J Biol Chem 1985;260:11619-11622.

55. Arnold PE, Lumlertgul D, Burke TJ, Schrier RW. In vitro versus in vivo mitochondrial calcium loading in ischemic acute renal failure. Am J Physiol 1985;248:845-848.

56. Humes HD. Role of calcium in pathogenesis of acute renal failure. Am J Physiol 1986;250:579-583.

57. Bellomo G, Orrenius S. Altered thiol and calcium homeostasis in oxidative hepatocellular injury. HEPATOLOGY 1985;5:876-882.

58. Mirabelli F, Salis A, Vairetti M, Bellomo G, Thor H, Orrenius S. Cytoskeletal alterations in human platelets exposed to oxidative stress are mediated by oxidative and $\mathrm{Ca} 2+$-dependent mechanisms. Arch Biochem Biophys 1989;270:478-488.

59. Wong PVK, Cheung WY. Calmodulin stimulates human platelet phospholipase A2. Biochem Biophys Res Commun 1979;90: 473-476.

60. McCord JM. Oxygen-derived free radicals in postischemic tissue injury. N Engl J Med 1985;312!159-163.

61. Bonventre JV, Cheung JC. Effects of metabolic acidosis on viability of cells exposed to anoxia. Am J Physiol 1985;249:C149C159.

62. Gores GJ, Nieminen AL, Dawson TL, Herman B, Lemasters JJ. Extracellular acidosis delays the onset of cell death in ATPdepleted hepatocytes. Am J Physiol 1988;255:C315-C322.

63. Gores GJ, Nieminen A, Wray BE, Herman B, Lemasters JJ. Intracellular $\mathrm{pH}$ during "chemical hypoxia" in cultured rat hepatocytes: protection by intracellular acidosis against the onset of cell death. J Clin Invest 1989;83:386-396.

64. Myagkaya G, van Veen $\mathrm{H}$, James J. Ultrastructural changes in rat liver sinusoids during prolonged normothermic and hypothermic ischemia in vitro. Virchows Arch [B] 1984;47:361-373.

65. Holloway CM, Harvey PR, Mullen JB, Strasberg SM. Evidence that cold preservation-induced microcirculatory injury in liver allografts is not mediated by oxygen-free radicals or cell swelling in the rat. Transplantation 1989;48:179-188.

66. Koizumi M, Ohkohchi N, Katoh H, Koyamada N, Fujimori K, Sakurada M, Andoh T, et al. Preservation and reflow damage in liver transplantation in the pig. Transplant Proc 1989;21:1323. 1326.

67. Iu S, Harvey PRC, Makowka L, Petrunka CN, Ilson RG, Strasberg SM. Markers of allograft viability in the rat: relationship between transplantation viability and liver function in the isolated perfused liver. Transplantation 1987;44:562-569.

68. McKeown CMB, Edwards V, Philips MJ, Harvey PRC, Petrunka CN, Strasberg SM. Sinusoidal lining cell damage: the critical injury in cold preservation of liver allografts in the rat. Transplantation 1988;46:178-182.

69. Fuller B. Storage of cells and tissues at hypothermia for clinical use. In: Bowler K, Fuller B, eds. Temperature and animal cells. Cambridge: Company of Biologists, 1987:341-342.

70. Bulkley GB. Free radical-mediated reperfusion injury: a selective review. Br J Cancer 1987;55:66-73.

71. Parks DA, Bulkley GB, Granger DN, Hamilton SR, McCord JM Ischemic injury in the cat small intestine: role of superoxide radicals. Gastroenterology 1982;82:9-15.

72. Parks DA, Granger DN, Bulkley GB, Shah AK. Soybean trypsin inhibitor attenuates ischemic injury to the feline small intestine. Gastroenterology 1985;89:6-12.

73. Stuart RS, Baumgartner WA, Borkon AM, Hall TS, Breda MA, Braun JD, Hutchins GM, et al. Five hour hypothermic lung preservation with oxygen free-radical scavengers. Transplant Proc 1985; 17:1454-1456.

74. Taylor AE, Martin D, Parker JC. The effects of oxygen radicals on pulmonary edema formation. Surgery 1983;94:433-438.

75. Baker GL, Corry RJ, Autor AP. Oxygen free radical induced damage in kidneys subjected to warm ischemia and reperfusion: protective effect of superoxide dismutase. Ann Surg 1985;202: 628-641.

76. Hoshino T, Maley WR, Bulkley GB, Williams GM. Ablation of free radical-mediated reperfusion injury for the salvage of kidneys taken from non-heartbeating donors. Transplantation 1988;45: 284-289.

77. Green CJ, Healing G, Lunec J. Evidence of free radical-induced damage in rabbit kidneys after simple hypothermic preservation and auto-transplantation. Transplantation 1986;41:161.

78. Gardner TJ, Stewart JR, Casale AS, Downey JM, Chambers DE. Reduction of myocardial injury with oxygen-derived free radical scavengers. Surgery 1983;94:423-427.

79. Stewart JR, Blackwell WH, Crute SL, Loughlin V, Greenfield LJ, Hess ML. Inhibition of surgically induced ischemia-reperfusion injury by oxygen free radical scavengers. $J$ Thorac Cardiovasc Surg 1983;86:262.

80. Stewart JR, Gerhardt EB, Wehr CJ, Sherman T, Merril WH, Hamman JW Jr, Bender HW Jr. Free radical scavengers and myocardial preservation during transplantation. Ann Thorac Surg 1986;42:390-393.

81. Sanfey H, Bulkley GB, Cameron JL. The pathogenesis of acute pancreatitis: the source and role of oxygen-derived free radicals in three different experimental models. Ann Surg 1985;201: 633-638.

82. Atalla SL, Toledo-Pereyra LH, MacKenzie GH, Cederna JP. Influence of oxygen-derived free radical scavengers on ischemic livers. Transplantation 1985;40:584-590.

83. Manson PN, Anthenelli RM, Im MJ. The role of oxygen free radicals in ischemic tissue in island skin flaps. Ann Surg 1983;198:87-90.

84. Del Maestro RF. An approach to free radicals in medicine and biology. Acta Physiol Scand 1980;492:153-168.

85. Freeman BA, Crapo JD. Biology of disease: free radicals and tissue injury. Lab Invest 1982;47:412-426.

86. Bulkley GB. The role of oxygen free radicals in human disease processes. Surgery 1983;94:407-411.

87. McCord JM. The superoxide free radical: its biochemistry and pathophysiology. Surgery 1983;94:412-414.

88. Fridowich I. The biology of oxygen radicals: the superoxide 
radical is an agent of oxygen toxicity; superoxide dismutases provide an important defense. Science 1978;201:875-880.

89. McCord JM, Fridovich I. The reduction of cytochrome $\mathrm{c}$ by milk xanthine oxidase. J Biol Chem 1968;243:5753-5760.

90. Metzger J, Dore SP, Lauterburg BH. Oxidant stress during reperfusion of ischemic liver: no evidence for a role of xanthine oxidase. HePATOLOGY 1988;8:580-584.

91. Marzi I, Zhong Z, Lemasters JJ, Thurman RG. Evidence that graft survival is not related to parenchymal cell viability in rat liver transplantation: the importance of nonparenchymal cells. Transplantation 1989;48:463-468.

92. Jaeschke H, Smith CV, Mitchell JR. Reactive oxygen species during ischemia-reflow injury in isolated perfused rat liver. J Clin Invest 1988;81:1240-1246.

93. Warren JS, Ward PA. Review: oxidative injury to the vascular endothelium. Am J Med Sci 1986;29:97-102.

94. Guarnieri C, Flamigni F, Caldarera CM. Role of oxygen in the cellular damage induced by re-oxygenation of hypoxic heart. J Mol Cell Cardiol 1980;12:797-808.

95. Marubayashi S, Dohi K, Sumimoto K, Oku J, Ochi K, Kawasaki $T$. Changes in activity of oxygen free radical scavengers and in levels of endogenous antioxydants during hepatic ischemia and subsequent reperfusion. Transplant Proc 1989;21:1317-1318.

96. Robert A, Nezamis JE, Lancaster C, Hanchar J. Cytoprotection by prostaglandins in rats. Prevention of gastric necrosis produced by alcohol, $\mathrm{HCl}, \mathrm{NaOH}$, hypertonic $\mathrm{NaCl}$, and thermal injury. Gastroenterology 1979;77:433-443.

97. Robert A. Current history of cytoprotection. Prostaglandins 1981;21:89-96

98. Friedman N, Park CR. Early effects of $3^{\prime}, 5^{\prime}$-adenosine monophosphate on the fluxes of calcium and potassium in the perfused liver of normal and adrenalectomized rats. Proc Natl Acad Sci USA 1968;61:504-508.

99. Katzung BG, Chatterjee K. Vasodilators \& the treatment of angina pectoris. In: Katzung BG, ed. Basic \& clinical pharmacology. Los Altos: Lange Medical Publication, 1984:133.

100. Steininger R, Mühlbacher F, Rauhs R, Roth E, Bursch W. Protective effect of PGI2 and diltiazem on liver ischemia and reperfusion in pigs. Transplant Proc 1988;20:999-1002.

101. Mora NP, Cienfuegos JA, Bernaldó de Quiros L, Tendillo F, Pereira F, Fores R, Alvarez I, et al. Successful liver allograft function after 24-hour preservation: cumulative effects of prostacyclin plus verapamil. Transplant Proc 1987;19:3932-3936.

102. Lambotte L, de Hemptinne B, Alvarez-Lopez A, Besse T. Effects of calcium blocking agents and prostaglandins $\mathrm{I} 2$ or $\mathrm{E} 2$ on the tolerance of the rat liver to ischemia. Transplant Proc 1988; 20:986.

103. Umeshita K, Monden M, Ukei T, Gotoh M, Nakano Y, Endoh W, Okamura $\mathrm{R}$, et al. Different cytoprotective effects of calcium blockers in hypothermic liver preservation. Transplant Proc 1989;21:1290-1291.

104. Murad F. Regulation and the role of cyclic metabolites. In: Cowley RA, Trump BF, eds. Pathophysiology of shock, anoxia and ischemia. Baltimore: Williams \& Wilkins, 1982:147-153.

105. Lambotte L, Pontegnie-Istace S, Otte JB, Kestens PJ. The effect of isoproterenol and Collins' solution on the preservation of canine livers with simple cooling. Transplant Proc 1974;6: 301-303.

106. Thomas GE, Levitsky S, Feinberg H. Chlorpromazine inhibits loss of contractile function, compliance and ATP in ischemic rabbit heart. J Mol Cell Cardiol 1983;15:621-628.

107. Mittnacht S Jr, Farber JL. Reversal of ischemic mitochondrial dysfunction. J Biol Chem 1981;256:3199-3201.

108. Chien KR, Abrams J, Serroni A, Martin JT, Farber JL. Accelerated phospholipid degradation and associated membrane dysfunction in irreversible ischemic, liver cell injury. J Biol Chem 1978;253:4809-4813.

109. Rangel DM, Bruckner WL, Byfield JE, Dinbar A, Yakeishi Y, Stevens GH, Fonkalsrud EW. Enzymatic evaluation of hepatic preservation using cell-stabilizing drugs. Surg Gyn Obstet 1969;129:963-972.

110. Sundberg R, Ar'Rajab A, Ahr'n B, Bengmark S. Improvement of liver preservation quality with UW solution by chlorpromazine pretreatment of the donor in an experimental model. Transplantation 1989;48:742-744.

111. Ozaki N, Tokunage $Y$, Wakashiro S, Ikai I, Morimoto T, Shimahara Y, Kamiyama Y, et al. Evaluation of cytoprotective drugs for liver preservation by pyridine nucleotide fluorometry. Surgery 1988;104:98-103.

112. Malis CD, Bonventre JV. Mechanism of calcium potentiation of oxygen free radical injury to renal mitochondria. J Biol Chem $1986 ; 261$ :14201-14208.

113. Lie TS, Seger R, Hong GS, Preissinger H, Ogawa K. Protective effect of aprotinin on ischemic hepatocellular damage. Transplantation 1989;48:396-399.

114. Santiago-Delpin EA, Figueroa I, Lopez R, Vazques J. Protective effect of steroids on liver ischemia. Am Surg 1975;41:683-695.

115. Goldyne ME. Prostaglandins and other eicosanoids. In: Katzung BG, ed. Basic and clinical pharmacology. Los Altos: Lange Medical Publications, 1984:217-226.

116. Moncada S, Gryglewski R, Bunting S, Vane JR. An enzyme isolated from arteries transforms prostaglandin endoperoxides to an unstable substance that inhibits platelet aggregation. Nature 1976;263:663-665

117. Moncada S, Vane JR. Prostacyclin: its biosynthesis and clinical potential. Phil Trans R Soc Lond [Biol] 1981;294:305-329.

118. Lefer AM, Ogletree ML, Smith JB, Silver MJ, Nicolaou KC, Barnette WE, Gasic GP. Prostacyclin: a potentially valuable agent for preserving myocardial tissue in acute myocardial ischemia. Science 1978;200:52-54.

119. Araki $H$, Lefer AM. Cytoprotective actions of prostacyclin during hypoxia in the isolated perfused cat liver. Am J Physiol 1980;238:H176-H181.

120. Sikujara O, Monden M, Toyoshima K, Okamura J, Kosaki G. Cytoprotective effect of prostaglandin I2 on ischemia-induced hepatic cell injury. Transplantation 1983;36:238-243.

121. Stryer L. Hormone action. In: Stryer L, ed. Biochemistry. New York: WH Freeman \& Co. 1981:853-854.

122. Ueda Y, Matsuo K, Kamei T, Ono H, Kayashima K, Tobimatsu M, Konomi K. Prostaglandin E1 but not E2 is cytoprotective of energy metabolism and reticuloendothelial function in the ischemic canine liver. Transplant Proc 1987;19:1329-1330.

123. Rush B, Merritt MV, Kaluzny M, van Schoick T, Brunden MN, Ruwart M. Studies on the mechanism of the protective action of 16,16-dimethyl PGE2 in carbon tetrachloride-induced acute hepatic injury in the rat. Prostaglandins 1986;32:439-454.

124. Todo S, Yokoi H, Podesta L, ChapChap P, Pan C, Okuda K, Kamiyama $Y$, et al. Amelioration of normothermic canine liver ischemia with prostacyclin. Transplant Proc 1988;20: 965-968.

125. Ontell SJ, Makowka L, Mazzaferro V, Trager J, Ove P, Starzl TE. The protective effect of SRI 63-441 on ischemic liver injury using the isolated perfused rat liver:combined protocol with superoxide dismutase. Transplant Proc 1988;20:972-973.

126. Monden M, Fortner JG. Twenty-four- and 48-hour canine liver preservation by simple hypothermia with prostacyclin. Ann Surg 1982;196:38-42.

127. Toledo Pereyra LH. Role of prostaglandins (PGI2) in improving the survival of ischemically damaged liver allografts. Trans Am Soc Artif Intern Organs 1984;30:390-394.

128. Gaber AO, Thistlethwaite JR Jr, Busse-Henry S, Aboushloe M, Emond $J$, Rouch D, Broelsch CE. Improved results of preservation of hepatic grafts preflushed with albumin and prostaglandins. Transplant Proc 1988;20:992-993.

129. Abecassis M, Falk J, Dindzans V, Lopatin W, Makowka L, Levy G, Falk R. Prostaglandin E2 prevents fulminant hepatitis and the induction of procoagulant activity in susceptible animals. Transplant Proc 1987;19:1103-1108.

130. Greig PD, Woolf GM, Sinclair SB, Abecassis M, Strasberg SM, Taylor BR, Blendis LM, et al. Treatment of primary liver graft nonfunction with prostaglandin E1. Transplantation 1989;48: 447-453.

131. Toledo-Peyrera LH, Simmons RL, Najarian JS. Effect of allopurinol on the preservation of ischemic kidneys perfused with plasma or plasma substitutes. Ann Surg 1974;180:780-782.

132. Parks DA, Bulkley GB, Granger DN. Role of oxygen free radicals 
in shock, ischemia, and organ preservation. Surgery 1983;94: 428-432.

133. Peterson DA, Kelly B, Gerrard JM. Allopurinol can act as an electron transfer agent: is this relevant during reperfusion injury? Biochem Biophys Res Commun 1986;137:76-79.

134. Nordström G, Seeman T, Hasselgren P-O. Beneficial effect of allopurinol in liver ischemia. Surgery 1985;97:679-683.

135. McCord JM, Fridowich I. Superoxide dismutase: an enzymic function for erythrocuprein (hemocuprein). J Biol Chem 1969; 244:6049-6055.

136. Olson LM, Klintmalm GB, Husberg BS, Nery JR, Whitten CW, Paulsen AW, McClure R. Superoxide dismutase improves organ preservation in liver transplantation. Transplant Proc 1988;20: 961-964.

137. Southard JH, Marsh DC, McAnulty JF, Belzer FO. Oxygenderived free radical damage in organ preservation: activity of superoxide dismutase and xanthine oxidase. Surgery 1987;101: 566-570.

138. Turrens JF, Mirza Z, Crapo JD, Freeman BA, Turrens JF, Mirza Z, Crapo JD, et al. Modulation of oxidant lung injury by using liposome-entrapped superoxide dismutase and catalase. Fed Proc 1985;44:2591-2595.

139. Marubayashi S, Dohi K, Sumimoto K, Sugino K, Ochi K, Kawasaki $T$. Role of free radicals in ischemic rat liver preservation: prevention of damage by vitamin $\mathrm{E}, \mathrm{CoQ} 10$, or reduced gluthatione administration. Transplant Proc 1988;20:974-975.

140. Sumimoto K, Inagaki K, Marubayashi S, Kawasaki T, Dohi K. Energy metabolism in warm ischemically damaged liver grafts after transplantation and protection by coenzyme Q10 pretreatment. Transplant Proc 1988;20:958-960.

141. Stryer L. Oxidative phosphorylation. In: Stryer L, ed. Biochemistry. New York: Freeman \& Co., 1981:312-313

142. Wahlberg JA, Love R, Landegaard L, Southard JH, Belzer FO. 72-hour preservation of the canine pancreas. Transplantation $1987 ; 43: 5-8$

143. Kalayoglu M, Sollinger HW, Stratta RJ, D'Alessandro AM Hoffmann RM, Pirsch JD, Belzer FO. Extended preservation of the liver for clinical transplantation. Lancet 1988;1:617-619.

144. Jamieson NV, Lindell S, Sundberg R, Southard JH, Belzer FO.
Evaluation of simplified variants of the UW solution using the isolated perfused rabbit liver. Transplant Proc 1989;21:12941295.

145. Wahlberg J, Jacobsson J, Tufveson G. Relevance of additive components of University of Wisconsin cold-storage solution: an experimental study in the rat. Transplantation 1989;48:400-403.

146. Sumimoto R, Jamieson NV, Wake K, Kamada N. 24-hour rat liver preservation using UW solution and some simplified variants. Transplantation 1989;48:1-5.

147. Moen J, Claesson K, Pienaar H, Lindell S, Ploeg RJ, McAnulty JF, Vreugdenhil PK, et al. Preservation of dog liver, kidney, and pancreas using the Belzer-UW solution with a high-sodium and low-potassium content. Transplantation 1989;47:940-945.

148. Belzer FO, Hoffman RM, Stratta RJ, D'Alessandro AM, Pirsch $\mathrm{JD}$, Kalayoglu M, Sollinger HW. Combined cold storageperfusion preservation of the kidney with a new synthetic perfusate. Transplant Proc 1989;21:1240-1241.

149. Nedelec JF, Capron-Laudereau M, Adam R, Dimicoli J, Gugenheim J, Patry J, Pin ML, et al. Liver preservation: 31P and 13C NMR spectroscopic assessment of liver energy and metabolism after cold storage in Collins, Marshall, Ringer's lactate and modified UW solutions. Transplant Proc 1989;21: 1327-1329.

150. Kamiike W, Watanabe F, Hashimoto T, Tagawa K, Ikeda Y, Mako $\mathrm{K}$, Kawashima $\mathrm{Y}$. Changes in cellular levels of ATP and its catabolites in ischemic rat liver. J Biochem 1982;91:1349-1356.

151. Sakurada M, Ohkohchi N, Kato H, Koizumi M, Fujimori K, Satomi S, Sasaki T, et al. Mitochondrial respiratory function, adenine nucleotides and antioxygenic enzymes in pig liver transplantation. Transplant Proc 1989;21:1321-1322.

152. Kamiike W, Burdelski M, Steinhoff G, Ringe B, Lauchart W, Pichlmayr $R$. Adenine nucleotide metabolism and its relation to organ viability in human liver transplantation. Transplantation 1988;45:138-143.

153. Palombo JD, Hirschberg Y, Pomposelli JJ, Blackburn GL, Zeisel SH, Bistrian BR. Decreased loss of liver nucleotides and energy charge during hypothermic preservation by donor pretreatment with glucose: a preliminary report. Transplant Proc 1989;21: 1299-1300. 